\title{
Power relations in the enactment of English language education policy for Chinese schools
}

\author{
Minglin Li \\ School of Education and Professional Studies, Griffith University, Australia \\ Email: minglin.li@griffith.edu.au
}

Tel: +61 737354081

\begin{abstract}
The scale of English language education in China is astounding, but recent research has shown that the latest national English education policy for Chinese schools has not been implemented successfully due to various reasons. One reason given for the lack of success is the impracticability of the top-down policy itself excluding teachers' involvement and neglecting the contextual constraints. Building on the theoretical framework of multi-levelled actors in language planning and language policy, and drawing on some key concepts in relation to power in Critical Language Policy research, this paper explores how a national English language curriculum that emphasises the international standards and norms in curriculum design has been enacted, ineffectively, by the key stakeholders through analysing the specific roles of three groups of key stakeholders involved in the EFL curriculum policy implementation.
\end{abstract}

Keywords: English language education policy; multi-level actors; power relations; critical language policy; curriculum enactment; Chinese schools

\section{Introduction}

The status and role of EFL (English as a foreign language) as a school subject since the foundation of the People's Republic of China in 1949 has fluctuated with the changing socio-political climate, but the current scale of EFL education in China is astounding (see e.g., Adamson, 2004, for a history of English education in China; $\mathrm{Hu}$, 2007 and Li, 2007, for information about the EFL policy of making English as a compulsory subject in Chinese primary schools starting from 2001). On entering the $21^{\text {st }}$ century and with China' increasingly important role on the global stage, education reform was perceived by the Chinese Communist Party (CCP) to be a top priority in order to develop human resources and allow China to be more involved in the world economy. EFL curriculum innovation for Chinese school, as part of basic education reform, was launched by the Ministry of Education (MOE) in 1999, aiming to promote all-round quality-oriented education focusing on the cultivation of students' 
creativity and ability to make practical and effective use of new knowledge. The new 2001 EFL Curriculum Standards (hereafter the 2001 Standards) commenced for implementation nation-wide in September 2001 (see e.g., Wang \& Lam, 2009, for a brief history of the English language curriculum reforms for Chinese schools), shifting the focus from traditionally on teaching and learning basic linguistic knowledge and linguistic skills to learners focusing on the quality of students' overall education through task-based, learner-centred and communicative language teaching (Cheng \& Gong, 2005; Wen \& Hu, 2007; see e.g., MOE, 2001).

However, it has been reported that the implementation of the 2001 Standards was unsuccessful due to various contextual constraints, (see e.g., $\mathrm{Hu}, 2005 ; \mathrm{Hu} 2007$; $\mathrm{Li}$, 2010; Nunan, 2003). One reason given for the lack of success is the impracticability of the top-down policy. The curriculum policy emphasises the international standards and norms in curriculum design, but excluding classroom teachers' involvement and neglecting the contextual and situational factors may have negative impact on its implementation (Hu, 2007; Li \& Baldauf, 2011). Yet, little has been researched into how the involvement of teachers as well as other key stakeholders at local levels has resulted in the ineffective EFL curriculum policy implementation. Bambose (2004) has discovered that when macro-level language policies trickle down from the top to the bottom, contradictory policies are adopted at various meso and micro levels and "what is implemented at a lower level is often different from what is prescribed at a higher level" (p. 61). This paper, building on the theoretical framework of multilevelled actors in language planning and language policy, and drawing on some key concepts in relation to power in Critical Language Policy (CLP) research, will explore how a well-designed national EFL curriculum has been enacted, ineffectively, by the key stakeholders through analysing the specific roles of the three groups of key stakeholders involved in the EFL curriculum policy implementation (more in the Research Methods section).

\section{Multi-levelled Language Planning / Language Policy and CLP research}

The literature normally employs the two terms of language planning and language policy synonymously although they are defined variously by scholars (Kaplan \& Baldauf, 1997). Language planning is broadly perceived as the organized activity to study language issues for solving language problems (see e.g., Cooper, 1989; Rubin \& Jernudd, 1971), while language policy is regarded as the goals of language planning (Cooper, 1989) or, in Bamgbose's (2004) words, an aspect of language planning and it is subject to the sanction of an authority. 
Language planning and language policy operates at macro, meso and micro levels in societies and actors involved in language planning process are multi-levelled (e.g., Ager, 2001; Cooper, 1989; Haarmann, 1990; Kaplan \& Baldauf, 1997; Shohamy, 2006; Spolsky, 2004). It is viewed most often as a macro activity, which is normally extended to the micro situation for implementation (Baldauf, 2005). In recent two decades, however, there have been an increasing number of studies focusing on language planning at the local level. Liddicoat and Baldauf (2008, p. 10) have reviewed a number of agents of language planning in local contexts and concluded that "language planning is not limited to government bodies with the power to impose their ideas through their own political dominance" (p. 10), but there is interaction between the micro and macro language planning. They assert that norms and expectations for the ways in which languages are used in local communities can be established by a macro-level institution, "but how this is realized is dependent on decisions made at other levels. No macro-level policy is transmitted directly and unmodified to a local context" (p. 11).

Bamgbose (2004) has observed three dimensions of the link between language planning and language policy, namely, rigor of treatment, inclusion, and sanction by an authority. Authority that sanctions a language policy, according to Bambose, does not have to be political. Rather, "there could be a hierarchy of authorities and levels of decisions matched by the status or power of the authority concerned" (Bamgbose, 2004, p. 64). Given this characterization of language policy, Bamgbose argues that a person or entity involved in language policy must be in a position of authority to be considered as a policy-maker. The government can be the higher-level making fundamental policy decisions, while lower-level decisions are consequential ones taken in the course of implementation and the actors can be agencies, groups or individuals. In such a policy decision-making hierarchy, "there is definitely correlation between power and policy-makers. Those who make policy tend to be those who have access to power and privilege" (Bamgbose, 2004, p. 73).

Power, struggle, and hegemony and ideology are some key concepts that have influenced the recent CLP research (e.g., Pennycook, 1994, 1998; Tollefson, 2002, 2006). For Foucault, power is in fact power relations that are embedded in people's habits and behaviours, in institutions and political systems (1996a). It is everywhere within society and cannot be concentrated just in the hands of a particular group of people (1978) and is coextensive with every social relationship (1980). Some people would try to control the conduct of others who in turn would try to avoid being controlled or try to control the conduct of others (Foucault, 1996b). According to 
Fairclough (2001), power is always the relations of social struggle which occurs between social groupings of various sorts, for instance, young and old, dominating and dominated groupings in social institutions, and the exercise of power can take place through language use. "Language is both a site of and a stake in class struggle, and those who exercise power through language must constantly be involved in struggle with others to defend (or lose) their position" (Fairclough, 2001, p. 28-29).

In CLP research, power is seen as implicit in policy-making process (Tollefson, 2006), and not all multi-levelled or multi-layered individuals exhibit the same amount of power (Johnson \& Johnson, 2014). In the sections that follow, how various multilevelled stakeholders interpret their responsibilities and how power plays out among them in the EFL curriculum policy enactment through language use are analysed based on Halliday's concepts of interpersonal metafunctions.

\section{Halliday's SFL - Interpersonal Metafunctions}

In the analysis of a text, various levels of languages can be addressed such as vocabulary, grammar and textual structure (Fairclough, 1992; 2001). In this study, the analysis has focused on two linguistic dimensions: 1) the choice of certain category of vocabulary - personal pronouns and modal auxiliaries; and 2) other language expressions explicitly showing social and power relations. For the focused analysis of personal pronouns and modal auxiliaries, Halliday's Systemic functional linguistics (SFL) (Halliday, 1994; Halliday \& Matthiesen, 2004) was used to examine relative social status of and power relations among the key stakeholders involved in the enactment of the EFL curriculum policy for Chinese schools.

Halliday and Matthiessen (2004, p. 29) believe that language does not only "construe human experience" but is always enacting as well: "enacting our personal and social relationships with the other people around us". Halliday's SFL deals with utterances and texts produced by speakers so as to convey their intended meanings through generalized metafunctions of language in everyday life. Among the three metafunctions - ideational, interpersonal, and textual - interpersonal metafunction concerns the building up and enacting social relationships through, for instance, modality and personal pronouns among other grammatical aspects to express speakers' judgement on or attitudes to the message they received, to show their relative social status, to indicate the role of the speakers in the communication and the social distance among them.

SFL was stimulated in part by Halliday's learning of Chinese and reading of Chinese grammar (Makoni \& Makoni, 2013), and was later introduced and applied to 
the studies of Chinese linguistics (see e.g., Hu, 2000; Li, 2001, 2002). Research shows that there are certain words in Chinese equivalent to the modal verbs expressing requirement, obligation and permission (Wei, 2006). By using modality speakers could express their opinions and show their judgment of the obligations involved in their statements to various extents: high (required): must, ought to, need, has to, is to; median (supposed): will, would, shall, should; and low (allowed): may, might, can, could (Halliday, 1994).

Interpersonal meanings are embodied in the person system, both as pronouns (e.g. she, you) and as possessive determiners (e.g. her, your) (Halliday \& Matthiessen, 2004). Pronominal choice has been indicated in Brown and Gilman's (1960) pioneering work to be affected by the perceived role relationship between the speaker and the hearer. According to Fairclough (2003), pronouns are a particular way in which social actors are represented and which in text can set up divisions and establish meanings about the particular and the universal. In studies of Chinese linguistics, pronominal choices could reflect the hierarchical social status of the people involved in a conversation. For instance, when three people A, B, and C have hierarchically superior to inferior social status, $\mathrm{C}$ should not use he/she to refer to $\mathrm{A}$ when talking to $\mathrm{B}$ or $\mathrm{B}$ to $\mathrm{A}$; and when $\mathrm{A}$ is talking to $\mathrm{C}$ about $\mathrm{B}$ or when $\mathrm{B}$ is talking to $\mathrm{C}$ about $\mathrm{A}$, it would not be appropriate for $\mathrm{A}$ or $\mathrm{B}$ to use he/she given the inferior status of C (Lü \& Jiang, 1985). Lü and Jiang have also indicated that the first person deixis we can be used in various contexts showing different positions the speaker puts himself/herself in: inclusive we will include you/you and I/we to be on the opposite side of he/she/they; exclusive we will put $I$ and he/she/they in the same group being opposite to you/you. In addition, while using $I$ to refer to oneself implies an arrogant attitude towards others, using we as a self-depreciatory form of $I$ will represent humbleness on the part of the speaker. The use of Chinese self-depreciatory terms, according to Zhang, Wu and Feng (2013), is one way to shorten the social distance between people by showing politeness in the power hierarchy in the finely-stratified society.

The analysis of pronoun use by the participants in this study were based on the studies of person deixis both in Chinese and English in order to reveal how they position themselves in the social relations and how they perceive themselves to be close to or distant from others. The following first and third personal pronouns in both singular and plural forms, and their reflexives and possessives were examined $-I$, myself, my; we, ourselves, our; he/she, himself/herself, his/her (there is no gender difference in pronouncing third person in Chinese); they, themselves, their. 
In addition to personal deixis and modal auxiliaries, further analysis in this paper was carried out to examine other explicit language expressions produced by the participants that are relevant to the themes of power, struggle and ideology control.

\section{Research Methods}

For the purpose of the present study, semi-structured interviews were conducted, through either one-to-one or focus group, with people at various levels involved in EFL education in Chinese schools in one of the most economically developed provinces in China. One-to-one interviewing was conducted with a key administrative officer from the Basic Education Department in the provincial Education Department and a key member of provincial Teaching and Research Department (TRD). Focus group interviewing was conducted with a group of four TRD members in the capital city of the selected province, with one coming from the city level and the other three from three districts immediately lower than the city level. Two groups of EFL teachers, one from a top secondary school in the capital city (5 teachers) and the other from various secondary schools in a rural area of another city in this province (6 teachers), also agreed to participate in the focus group interviewing.

General strategies used to make culturally appropriate conversation in China should take into account the interactants' levels of social status in order to get the information needed. First of all, politeness is of great importance. To show respect to superiors and to teachers is strongly advocated in China. Therefore, when conducting interviews, it was necessary to be deferential to administrators and to participants older than the researcher, and to be modest and amiable to teachers who were younger. Secondly, it was made clear to the participants that the researcher was not evaluating them but seeking their assistance in understanding certain issues relevant to EFL education in Chinese schools. This should help to avoid embellished descriptions of their roles or their providing information that fitted interviewer stereotypes.

Thirdly, the interview venues were selected by the participants themselves so that they might feel comfortable to talk more openly.

When conducting the interviews, it was initially explained to the participants that the purpose of the interview was for research that no personal names or school names would be used, and that no individual would be identifiable. The participants were then asked for permission to have the interviews tape-recorded. To enable the participants to talk more freely, the interviewing technique adopted in this study was effectively based on the semi-structured interview pattern, i.e. the way the data were collected slightly varied according to the different characteristics of the interviewees, 
ranging from partially structured to completely informal and unstructured. During the impromptu conversation, the researcher tried to avoid leading questions and tried not to push the participants to give expected answers. The key questions relating to the roles of various stakeholders were introduced in a very natural way, leaving open the chance for the participants to express what they really thought and felt.

Interviews were conducted in Chinese and were transcribed as characters in the original Chinese language. Qualitative content analysis was used through thematic analysis (Wilkinson, 2004). In analysing the data, the individual officer, the TRD member, the TRD group and the two groups of EFL teachers were respectively considered as five individual cases (Miles \& Huberman, 1994). Relevant themes from all five data sets were translated, categorized and then coded. Later the codes were used to retrieve details from the data, which were presented as quotations. All the quotations were then translated into English. In translating data, the back-translation procedure suggested by Weber (1990) was used to check the validity of the translation. The text in English was translated back into Chinese and then compared with the original. In addition, the context impact on the participants that can help better understand and interpret their meanings was taken into consideration when translating and analysing the data (Krippendorff, 1980).

\section{Relationships among the key stakeholders of the EFL education policy enactment}

Based on the quotations from the interviewees that include various linguistic features and language expressions relevant to power relations, which are underlined for clarity in the analysis, findings are presented and discussed in this section. Codes were created in order to identify quotations, with labels of AO for the provincial administrative officer, TRDI for the TRD individual member at the provincial level and TRDG for the TRD group, T1 for EFL teachers in the capital city and T2 for the other EFL teacher group.

\section{EFL education policy development process}

The AO described in detail the development process of language education policy in general, and school curriculum in particular. He explained that the development of national educational policies concerning curriculum reform for basic education in Chinese schools was based on a top-down hierarchical process, which is summarized in Figure 1. 
The AO indicated that the State Council specified programmatic policy requirements in the form of policy documents concerning curriculum reform. Following those policy requirements, the MOE organized the specific reform activities, i.e., designing the new curriculum for each school subject including EFL, and specifying further requirements about how to implement the policy. These curricula and requirements were considered to be policy documents at the state level, and were forwarded to each Education Department at the provincial level. Two departments at the provincial level were directly in charge of the national policy implementation through training programmes and helping with the selection of teaching materials: the Administrative Department of Basic Education (ADBE) and the Teaching and Research Department (TRD). The ADBE forwarded the national policy documents to the TRD and lower-level ADBE for implementation with minor changes where necessary according to the actual situation in each province.

The TRD at the provincial level then specified teaching activities, based on the policy documents and requirements at both the state and the provincial levels, for guiding the lower-level TRDs in the implementation. The Education Department at local levels, both the ADBE and the TRD, organized the implementation activities: teacher training and classroom teaching. Schools and classroom teachers, guided by TRD members at the local level, were required to implement the curriculum by using the prescribed new series of textbooks in classroom practice.

The TRD members and both groups of EFL teachers have confirmed their duties assigned to them in implementing the national English curriculum. Further analysis of linguistic features of their accounts will show what their attitudes are towards their assumed roles in the curriculum development.

\section{Participants' perspectives on their status in the EFL curriculum policy enactment}

The AO confirmed the authoritative role of the state government in making policies and of the MOE making relevant education policies and curricula for schools. The AO also pointed out that it was the experts in relevant areas who had played a decisive role in the design of the curricula for Chinese schools, but the education officials at provincial level played a quite minor part in the process. Yet the AO pointed out:

$A O$ : So far as the promotion of the new curriculum reform is concerned, I think it should rely more on the guidance of the policies from the Administrative Department of Education, more government driven. .... We have always been emphasizing that this is a government action, and joint effort should be made in 
implementation by administrative department and teaching and research department.

The use of the modal auxiliary should, reinforced by the word "emphasizing", shows the AO is stressing that the government has the responsibility to lead the curriculum reform, and the ADBE holds a more powerful position over the TRDs. However, it is also obvious that for the AO the TRD is an indispensable unit although he used the pronoun we to separate administrative officers in the education department from TRD staff who are supposed to organize teaching activities in schools.

Based on what was described by the TRDI, the TRD functioned "as a platform" in implementing the national English curriculum, and the relationship between TRDs and school teachers was supposed to be cooperative, collaborative and supportive in order to do research to inform teaching:

TRDI: Well, of course we do [follow national policy when supervising teachers]! What do we TRD members do? We make [the policies from higher levels] known to lower levels and report back to higher levels [issues raised during policy implementation at lower levels]. We act as a platform, .... We are a platform, Teaching and Research is a platform.

The TRDI took the TRD as a unit and as a team by using we when he described their main role as the implementer and disseminator of the policies from superior levels. The usage of "of course" has not only strongly and effectively emphasized their implementer role but also revealed their powerless position compared to the Administrative Department at the same level and above.

The TRDG confirmed in the following utterances the hierarchical relations while signaling their powerlessness in dealing with issues arising from English language teaching in schools:

TRDG: [Our] immediate leader is the TRD a level higher. They supervise us. Policy documents are obtained from there. We just do whatever they tell us to do.

If there are some issues, we would talk to them directly, but, we may just grumble over something that is decided by higher levels. Feeling, um, what could be done is just reporting, but ... (didn't finish). 
Too weak! I don't think there is anything the TRD at the upper level can do about it.

They felt so helpless when they said that they did not believe they could contribute to the policy making nor could they believe the TRD at higher levels would be strong enough to have their voices heard by policy makers. There is something noteworthy herein about the use of we/us and they/them by the TRDG. It can show that the TRDG at local levels have excluded TRD at provincial level from their group, regarding themselves as inferior passively following orders from above. However, the use of third person deixis may also imply that lower-level TRDs were to some extent resentful of the fact that they would not be able to do what they thought they should but had to obey their superiors.

As both the TRDI and the TRDG pointed out, TRDs would guide the teachers in improving their language proficiency and skills, and their teaching ability in order to deliver a good lesson. Meanwhile, they would help teachers to change their attitudes, although they thought it was not an easy job, towards the education reform aiming at quality education. It has also been reported by the TRDI that some teachers are not happy with the TRDs following the government directions in quality education but ignoring the test pressure and they would, in their classroom practice, do what they think to be appropriate which is teaching to the test. What TRDs could do has been trying hard to help teachers to improve teaching quality without negatively impacting on achieving high examination scores. However,

TRDI: The current situation is, [the administrative officers in] the provincial Education Department, uh, including us (TRD members), often go down to make $\underline{\text { inspections }}$ or spot checks, uh, more are crying wine and selling vinegar, 'cause the entrance examination is just too stressful.

What the TRDG said below proved the pressure of the entrance examination on both TRDs and classroom teachers:

$T R D G:$ I often tell the teachers that you try your best to tell the kids to memorize them (vocabulary), but when I design the test paper I won't test this word. I said $\underline{I}$ would not test this word, but I could not guarantee the higher-level would not test it. 
This is true according to the EFL teacher participants in this study (see also Li, 2011). Yet, the use of $u s$ by the TRDI, and what has been said by TRDs unquestionably show that an authoritative position is being claimed by TRDs over teachers who are supposed to follow in their teaching the TRDs' directions. And selfimportance can also be sensed through the use of $I$ by one of the TRDG.

The EFL teachers who participated in this study (T1 and T2) showed their various degrees of knowledge and understanding of the new English curriculum, and expressed their concerns in various ways in how the curriculum could play its guiding role in English teaching and learning in Chinese schools. T1 commented that the new English curriculum was very well designed from the theoretical perspective but it was too difficult to implement with too high goals for students and teachers to achieve. As they mentioned below the goals were impractical because EFL classroom teachers had not been involved in the curriculum development but experts organized by the MOE had. The third personal pronouns he/she and they were used by the EFL teachers to refer to the English curriculum developers, emphasizing the different social groups they belonged to in the education system.

T1: He/She does not know about the current teaching and learning situations in schools! That's why the curriculum they designed, you can see, obviously cannot be put into practice in our Chinese context.

I think those people who designed the curriculum really knew nothing about the current English teaching and learning situations in China! They did not know.

T1 used our here a) to stress their own knowledge about local situation, which seems not to have been taken into consideration by the curriculum developers, and b) to show that they really care for students' education as being part of students' learning as well as a member of the Chinese society. The frequent use of third person pronouns here may also show that teachers are unwilling to accept that teachers would have no say in deciding what knowledge should be delivered to their students and how.

T1 said that it worked similarly in the selection of textbooks for schools where administrative officials' interference existed:

The textbooks we are using were selected by the Basic Education unit at the [city level] Education Department. They were not selected by people / person in charge of school teaching. 
Whether or not they (people selected textbooks) have knowledge about English language we cannot tell. We do not know either whether they have consulted teachers. They ordered them for us. They TRDs sometimes are not involved either.

The use of they and we by the T1 has positioned educational officials and EFL practitioners in two opposite sides. The officials may not have expertise in the field of EFL education, but they are keen to exercise their power in making decisions for the TRDs and EFL classroom teachers. This kind of administrative intervention, according to T1, is not helping with the English language education in schools.

T2 have little knowledge about the curriculum because "we have not participated in any training, none of us has." For them, the textbook was the curriculum, and new ideas would be passed on to them or through observing some demonstration lessons:

T2: Every year there is a meeting organized by TRD, will go there to get to know about the guidelines from upper level, one will go and then come back to pass on the message, um, briefly, about the requirements.

[The team leader] will go up for a meeting and then come down to pass on the message.

They frequently used "up" and "down" to show, unquestioningly, their lower position compared to TRD or Education Department. This is consistent with the descriptions by the other participants of the current hierarchical system under which people who have higher social status possess more power to influence people who have a lower social status.

\section{Participants' perspectives on others' status in the EFL curriculum policy enactment}

In terms of the roles TRDs and EFL teachers should play in the curriculum implementation, attitudes and expectations vary among different parties, the part TRD plays in particular from the eyes of EFL teachers. For the EFL teachers, TRDs are not positioning them appropriately by considering themselves as being more authoritative than teachers. The following quotations can explicitly show that teachers are not very pleased with TRD's superior role due to their lack of up-to-date knowledge about EFL 
teaching and learning in current Chinese schools. The increased differentiation between TRDs and teachers, supervising and being supervised, could also be seen from the use of the third personal pronouns:

T1: In here, there are many TRD people. They, ah, they are officials, aren't they?

Those TRD staff, they haven't, like what we are doing now (referring to the researcher of the present study talking with teachers about English teaching and learning in their school), sat down there with some teachers in order to really find out the current situation of English teaching and learning and the approaches. They haven't done so! What can only be said is that the TRDs nowadays, "I come to supervise your teaching, for you to teach this lesson well." The lowest level of teaching and research!

They did come out of the classroom, they used to be teachers, yes, but it won't do if they have not been teaching for a long time. To my knowledge, some of the TRD members are not even as open-minded as [Teacher X]!

Not sufficient experiences! $\underline{\mathrm{He} / \mathrm{she}}$ hasn't been in teaching, in education, for a long time, after some long time he/she would not be able to understand. $\underline{\mathrm{He} / \mathrm{She}}$ may have had some experience from previous teaching, but it's hard to tell when he/she does not teach in classrooms but only observe teachers.

In terms of teachers' responsibilities, both the $\mathrm{AO}$ and TRDs were unanimous in that teachers would play a crucial role in curriculum implementation. In relation to teachers' involvement in decision-making process, however, the AO has used in many occasions the third personal pronouns to exclude the teachers from the authoritative group:

$A O$ : This is how it works. $\underline{\mathrm{He}}$ (teacher) can put forward his own opinions and suggestions concerning some problems he has found in the implementation, but mostly only suggestions. It is the administrative departments that make policies. When the administrative officers make policies then, they will mostly rely on experts. The role teachers have is not a very important one. ... Even though they are given the opportunity to express their views, it is possible that they don't have 
any better ideas. .... But it is the reality. If you give them the opportunity to do this, they do not necessarily have the capabilities required!

TRDs have also showed their lack of confidence in teachers' capability to implement the national English curriculum that involves new concepts and directives for their teaching, either in the selection of teaching approaches / techniques, or in the understanding of the new materials.

TRDI: Teachers, uh, now teachers have some misunderstandings. We provide teachers with various kinds, all kinds of training opportunities, train teachers, again and again, in this, un, concept. We repeatedly tell them, you are using the textbook to teach (students), but you are not there repeating the language forms in the textbook (to the students). But, uh, there are many teachers, they won't change, yeah, they won't change this notion of theirs. ... This situation is what we have been making effort to change.

TRDG: Teachers really, uh, when talking about completely grasping the content of the textbook, that is to what extent the textbook content should be delivered to students, then to what extent the knowledge should be expanded considering the content in later sections of the textbook, quite a lot of teachers do not know well. ... We train teachers how to prepare lessons, section by section. However, even though it is done in this way, he/she just can't understand it completely. I feel that there is something here, um, that he/she, the teacher, ... has some problem in the depth of understanding (the textbook).

What has been described might be true in relation to teachers' capability and their readiness for implementing the new curriculum. Findings in the studies of $\mathrm{Li}$ (2010; 2011) and Li and Baldauf (2011) showed that teachers did not have time or opportunities for their professional development due to various reasons; and if some of them did, the teacher training programs they had attended to were not quite satisfactory. In the present research, EFL teachers have also voiced their own concerns, such as their awkward position between test pressure from all levels and their own beliefs in what and how English language should be taught in their classes. In addition, they also expressed their wish to contribute albeit a little to the EFL education policy development, but their powerless position seemed to make it impossible, which can be seen from the following: 
T1: I am not here to discourage you Ms (researcher). You may find out problems (through this research) and solutions, but to what extent it can be useful, well, uh....

\section{More voices to drive social change}

The quote above could best summarize the social realities in present China - officials with higher administrative ranking are superior to those with lower ranking; administrative officials are more powerful than professional staff. To be specific in relation to EFL education in Chinese schools, the findings from this study show that the state government, the MOE, and the administrative department in Education are in the position as the powerful groups that can provide advice, suggestions and directives for TRDs and teachers to follow. This is the genuine reflection of the centralized leadership with the CCP being the top leader. Under this highly centralized political system, there is only "one leader, one party, one ideology, and one voice" (Zhou, 2003, p. 6). The MOE and the local education departments have the responsibility to transmit the government' ideology and the CCP's views to school teachers and students (Li, 2011). This typical top-down policy making without listening to the voices of teachers from local schools and taking into consideration of teaching and learning realities has in fact led to the ineffective EFL curriculum policy enactment (Hu, 2007; Li, 2010). In such a hierarchical society, TRDs and EFL teachers are positioned as the common people - the opposite of leaders - who belong to the group with the lowest social status in developing language education policies. The lack of ownership, or the unavailability of communicative rational driven action in Habermas' $(1984,1987)$ words, could account for the breakdowns in communication among different groups involved in curriculum formulation and implementation when no action is coordinated by reasoned argument, consensus or cooperation.

Interestingly, evidence of power-claim and control-resistance could be traced between the TRDs and teachers. The use of inclusive pronoun by the TRDs has put themselves into we-community but excluded teachers from theirs, equalising their power positions over teachers (Fairclough, 2003) and authorising themselves to supervise and guide teachers from they-community. Teachers, on the other hand, have used they frequently to put them in a different group and distance themselves from those "officials", while in their teaching refused to follow TRDs' suggestions. TRDs have claimed that they have made constant endeavour to help teachers in understanding the new concept of quality education, suggesting their greater 
knowledge and insight than those of teachers hence the power to determine teachers' thinking and teaching. Teachers do not appreciate TRDs' effort though but interpret it as authority showing-off while challenging the guidelines from TRDs and educational officials verbally as well as in their classroom teaching. Having been in different positions, TRDs and teachers have developed various educational ideologies. While TRDs are trying to impose their ideologies upon teachers, teachers are using their own ways to teach showing their resistance to the ideologies imposed by the TRDs and relevant education policies. Having powers to determine what should be taught or which linguistic norms are "correct" or "appropriate" is an important aspect of social and ideological power, and therefore a focus of ideological struggle (Fairclough, 2001, p. 73). The power-driven action of the officials / leaders has undoubtedly led to the teachers' unwillingness or resistance in following the directives from the superior, which this paper would argue is a covert factor that has hindered the EFL education reform for Chinese schools.

However, Shanghai's recent success in implementing a Westernised curriculum proves that it is possible to empower the locals by giving "a relatively high degree of autonomy to formulate, implement and experiment with curriculum reforms" (Tan, 2013, p. 3). This is the evidence of social progress, of the effort the Chinese government is making in moving towards a more equal distribution of power by empowering the used to be powerless in order to create a more just society (Foucault, 1983). What can also been seen from the findings of this research is the EFL teachers' awareness of the social problem and their courage to challenge the "one party, one voice" system. They resist to some extent to implement the top-down EFL education policy, albeit it is well-developed, partly because they have their students' best interest in their hearts - help students to get higher scores for entering higher level education (Li \& Singh, 2015) - and partly because they regard themselves to be part of the Chinese community who should not be indifferent to social change ( $\mathrm{Li}, 2010)$ but responsible for its development. Their resistance and challenges to the authorities alone is a sign of social and cultural progress.

\section{Acknowledgement}

Part of the study was funded by the School of Education and Professional Studies at Griffith University. The author would like to thank her colleagues Associate Professor Sue Thomas and Dr Benjamin Williams for their valuable comments and suggestions. The author is also grateful to the Griffith Institute for Educational Research for the support while the paper was in the process of being revised. A special thank you goes also to the anonymous reviewers for their constructive and insightful feedback. 


\section{References}

Adamson, B. (2004). China's English: A history of English in Chinese education. Hong Kong: Hong Kong University Press.

Ager, D. (2001). Motivation in language planning and language policy. Clevedon, UK: Multilingual Matters.

Baldauf, R. B., Jr. (2005). Language planning and policy research: An overview. In E. Hinkel (Ed.), Handbook of research in second language teaching and learning (pp. 957-970). Mahwah, New Jersey: Lawrence Erlbaum Associates.

Bamgbose, A. (2004). Language planning and language policy: Issues and prospects. In P. G. J. van Sterkenburg (Ed.), Linguistics today: Facing a greater challenge (pp. 61-88). Piladelphia, PA, USA: Benjamins Publishing Company.

Brown, R., \& Gilman, A. (1960). The pronouns of power and solidarity. In D. Hymes (Ed.), Language in culture and society (pp. 234-244). Cambridge, MA: MIT Press.

Cheng, X. \& Gong, Y. (2005). Yingyu Kecheng Biaozhun de Lilun Jichu [Theoretical assumptions underlying the English curriculum]. Curriculum, Teaching Material, and Methods, 25 (3), 66-71.

Cooper, R. L. (1989). Language planning and social change. Cambridge: Cambridge University Press.

Fairclough, N. (1992). Discourse and social change. Cambridge: Polity Press.

Fairclough, N. (2001). Language and power ( $2^{\text {nd }}$ ed.). Harlow, England; New York: Longman.

Fairclough, N. (2003). Analysing discourse: Textual analysis for social research. London: Routledge.

Foucault, M. (1978). The history of sexuality. Volume 1: The will to knowledge (1976, translated by Robert Hurley). Harmondsworth: Penguin.

Foucault, M. (1980). Power and strategies. In C. Gordon (Ed.), Power/knowledge: Selected interviews and other writings 1972-1977 (pp. 134-145). New York: Pantheon Books.

Foucault, M. (1983). Afterword: The subject and power. In H. L. Dreyfus \& P. Rabinow (Eds), Michel Foucault: Beyond Structuralism and hermeneutics (pp. 208-226). Chicago: University of Chicago Press.

Foucault, M. (1996a). Problematics. In S. Lotringer (Ed.), Foucault live: Collected interviews 1961-1984 (pp. 416-422). New York: Semiotext(e). 
Foucault, M. (1996b). The ethics of the concern for self as a practice of freedom. In S. Lotringer (Ed.), Foucault live: Collected interviews 1961-1984 (pp. 432-449).

New York: Semiotext(e).

Haarmann, H. (1990). Language planning in the light of a general theory of language: A methodological framework. International Journal of the Sociology, 86, 103126.

Habermas, J. (1984). Reason and the rationalization of society. Volume 1 of The Theory of Communicative Action, English translation by Thomas McCarthy. Boston: Beacon Press (originally published in German in 1981).

Habermas, J. (1987). Lifeworld and system: A critique of functionalist reason. Volume 2 of The Theory of Communicative Action, English translation by Thomas McCarthy. Boston: Beacon Press (originally published in German in 1981).

Halliday, M. A. K. (1994). An introduction to functional grammar ( $2^{\text {nd }}$ ed.). London: Edward Arnold.

Halliday, M. A. K. \& Matthiessen, C. (2004). An introduction to functional grammar ( $3^{\text {rd }}$ ed.). London: Hodder Arnold.

Hu, G. (2005). English language education in China: Policies, progress, and problems. Language Policy, 4(1), 5-24.

Hu, Y. (2007). China's foreign language policy on primary English education: What's behind it? Language Policy, 6(3-4), 359-376.

Hu, Z. (2000). Guided reading [A] on M. A. K. Halliday, 1985/1994. An Introduction to Functional Grammar. Beijing: Foreign Language Teaching and Research Press.

Johnson, D. C., \& Johnson, E. J. (2014). Power and agency in language policy appropriation. Language Policy, DOI: 10.1007/s10993-014-9333-z.

Kaplan, R. B., \& Baldauf, R. B., Jr. (1997). Language planning: From practice to theory. Philadelphia: Multilingual Matters.

Krippendorff, K. (1980). Content analysis: An introduction to its methodology. Beverly Hills, CA: Sage.

Li, M. (2007). Foreign language education in primary schools in the People's Republic of China. Current Issues in Language Planning, 8(2), 148-161.

Li, M. (2010). EFL teachers and English language education in the PRC: Are they the policy makers? The Asia-Pacific Education Researcher, 19(3), 439-451. 
Li, M. (2011). Shaping socialist ideology through language education policy for primary schools in the PRC. Current Issues in Language Planning, 12(2), 185204.

Li, M., \& Baldauf, R. B. Jr. (2011). Beyond the curriculum: Issues constraining effective English language teaching: A Chinese example. TESOL Quarterly, 45(4), 793-803.

Li, M., \& Singh, P. (in press). Accounting for classroom curriculum: Test driven EFL practices. In I. Liyanage \& B. Nima (Eds.), Multidisciplinary research perspectives in education: Shared experiences from Australia \& China. Rotterdam, the Netherlands: Sense Publishers.

Li, Z. (2001). Interpersonal meanings of epistemic modality in academic discourse. Foreign Language Teaching and Research, 33 (5), 353-358.

Li, Z. (2002). Interpersonal meaning in discourse. Shanghai: Shanghai Foreign Language Education Press.

Liddicoat, A. J., \& Baldauf, R. B., Jr. (2008). Language planning in local contexts: Agents, contexts and interactions. In A. J. Liddicoat, \& R. B. Baldauf, Jr. (Eds.), Language planning and policy: Language planning in local contexts (pp. 3-17). Clevedon: Multilingual Matters.

Lü, S. \& Jiang, L. (1985). Jindai Hanyu Zhishi Daici [Demonstrative Pronouns in Early Modern Chinese]. Shanghai: Xuelin Publishing House.

Makoni, S., \& Makoni, B. (2013). Critical Applied Linguistics. In Carol A. Chapelle (Ed.), The Encyclopedia of Applied Linguistics. Blackwell Publishing Ltd.. DOI: 10.1002/9781405198431.wbea10271.

Miles, M. B., \& Huberman, A. M. (1994). Qualitative data analysis: An expanded sourcebook ( $2^{\text {nd }}$ ed.). Thousand Oaks, CA: Sage.

MOE (2001). Quanrizhi yiwu jiaoyu putong gaoji zhongxue yingyu kecheng biaozhun (shiyangao) [English curriculum standards for compulsory education and senior secondary education (Trial)]. Beijing: MOE.

Nunan, D. (2003). The impact of English as a global language on educational policies and practices in the Asia-Pacific region. TESOL Quarterly, 37(4), 589-613.

Pennycook, A. (1994). The cultural politics of English as an international language. London: Longman.

Pennycook, A. (1998). English and the discourses of colonialism. London: Routledge. Rubin, J., \& Jernudd, B. H. (1971). Introduction: Language planning as an element in modernization. In J. Rubin, \& B. H. Jernudd (Eds.), Can language be planned? 
Sociolinguistic theory and practice for developing nations (pp. xiii-xxiv).

Honolulu: The University Press of Hawaii.

Shohamy, E. (2006). Language policy: Hidden agendas and new approaches.

London; New York: Routledge.

Spolsky, B. (2004). Language Policy. Cambridge, New York: Cambridge University Press.

Tan, C. (2013). Learning from Shanghai. Lessons on Achieving Educational Success. Singapore: Springer.

Tollefson, J. W. (Ed.) (2002). Language policies in education: Critical issues.

Mahwah, NJ: Lawence Erlbaum.

Tollefson, J. W (2006). Critical theory in language policy. In T. Ricento (Ed.), An introduction to language policy: Theory and method (pp. 42-59). Malden, MA: Blackwell Publishing.

Wang, Q. (2007). The national curriculum changes and the effects on English language teaching in the People's Republic of China. In J. Cummins \& C. Davison (Eds.), International handbook of English language teaching (pp. 86105). New York: Springer.

Wang, W. \& Lam, Agnes S. L. (2009). The English language curriculum for senior secondary school in China: Its evolution from 1949. RELC Journal, 40 (1), 65-82. DOI: $10.1177 / 0033688208101447$.

Weber, R. P. (1990). Basic content analysis (2 ${ }^{\text {nd }}$ ed.). Newbury Park, CA: Sage. Wei, Z. (2006). Metaphors of modality in English and Chinese: A contrastive study. Modern Foreign Languages, 31 (3), 263-272.

Wen, Q., \& Hu, W. (2007). History and policy of English education in mainland China. In Y. H. Choi, \& B. Spolsky (Eds.), English education in Asia: History and policies (pp. 1-31). Seoul, South Korea: Asia TEFL.

Wilkinson, S. (2004). Focus group research. In D. Silverman (Ed.), Qualitative research: Theory, method and practice ( $2^{\text {nd }}$ ed.) (pp. 177-199). London; Thousand Oaks, CA: Sage.

Wilson, J. (1990). Politically speaking: The pragmatic analysis of political language. Oxford, UK: Basil Blackwell.

Zhang, S., Wu, X., \& Feng, Y. (2013). An analysis of cultural differences in Chinese and English first-person deixis from the perspective of pragmatic empathy. Theory and Practice in Language Studies, 3(10), 1868-1872. 
Zhou, J. (2003). Remaking China's public philosophy for the twenty-first century.

Westport, CT: Praeger Publishers; an imprint of Greenwood Publishing Group, Inc. 